\title{
SISTEM INFORMASI GEOGRAFIS JALUR OBYEK WISATA PROPINSI JAWA TENGAH DENGAN METODE DJISTRAK
}

\author{
Taufik Kurnialensya ${ }^{1}$, Jarot Dian Susatyono ${ }^{2}$ \\ ${ }^{1}$ Desain Grafis, STEKOM, ${ }^{2}$ Sistem Informasi \\ Jl. Majapahit 605 Pedurungan Semarang 50193 \\ E-mail :taufik@stekom.ac.id ${ }^{1}$,jarot@stekom.ac.id ${ }^{2}$
}

\begin{abstract}
ABSTRAK
Jawa Tengah merupakan sebuah Propinsi yang berada di Indonesia yang terletak di bagian tengah Pulau Jawa. Propinsi ini berbatasan dengan Propinsi Jawa Barat di sebelah barat, Samudra Hindia dan Daerah Istimewa Yogyakarta di sebelah selatan, Jawa Timur di sebelah timur, dan Laut Jawa di sebelah utara. Secara administratif, Propinsi Jawa Tengah terdiri atas 29 kabupaten dan 6 kota. Pencarian jalur terpendek merupakan suatu permasalahan untuk menemukan sebuah jalur antara dua node dengan jumlah bobot minimal. Pada kasus pencarian jalur tercepat antara dua lokasi yang berbeda dalam sebuah peta, node akan merepresentasikan lokasi wisata, pada peta dan bobot merepresentasikan waktu yang dibutuhkan untuk melakukan perjalanan antara dua lokasi. Berbasis mobile dapat membantu dalam penentuan jalur terpendek, dengan menggunakan Google Map API. Tingkat keakuratan mencapai $85 \%$
\end{abstract}

Kata Kunci: $S I G$, mobile, dijkstra

\begin{abstract}
S
Central Java is a province in Indonesia which is located in the central part of Java Island. The province is bordered by West Java Province in the west, Indian Ocean and Special Region of Yogyakarta in the south, East Java in the east, and Java Sea in the north. Administratively, Central Java Province consists of 29 districts and 6 cities. The shortest path search is a problem for finding a path between two nodes with a minimum number of weights. In the case of finding the fastest path between two different locations on a map, the node will represent a tourist location, on the map and the weight represents the time needed to travel between the two locations. Mobile based can help in determining the shortest path, by using the Google Map API. The accuracy rate reaches $85 \%$.
\end{abstract}

Keywords: GIS, mobile, dijkstra

\section{PENDAHULUAN}

\subsection{Latar Belakang}

Dalam kehidupan ini permasalahan pencarian jalur terpendek merupakan sebuah kajian yang menarik, terutama dalam hal efisiensi waktu perjalanan antara satu lokasi ke lokasi lainnya. Hal ini akan sangat berguna untuk diimplementasikan pada beberapa kasus yang membutuhkan tingkat efisiensi waktu tinggi seperti pengiriman barang, pencarian lokasi, dan sebagainya.

Dengan memperoleh jalur terpendek antara dua lokasi, maka tingkat efisiensi waktu yang dibutuhkan untuk melakukan perjalanan antara dua lokasi tersebut akan semakin baik.

Pencarian jalur terpendek merupakan suatu permasalahan untuk menemukan sebuah jalur antara dua node dengan jumlah bobot minimal. Pada kasus pencarian jalur tercepat antara dua lokasi yang berbeda dalam sebuah peta, node akan merepresentasikan lokasi pada peta dan bobot merepresentasikan waktu yang dibutuhkan untuk melakukan perjalanan antara dua lokasi tersebut. Salah satu metode yang dapat digunakan untuk menyelesaikan permasalahan pencarian jalur terpendek yaitu dengan menggunakan algoritma Dijkstra.

Algoritma dijkstra akan mencari jalur terpendek mulai dari node awal sampai node tujuan. Algoritma ini akan membandingkan bobot terkecil dari node awal sampai ke node tujuan untuk menemukan jalur paling efisien.

\subsection{Rumusan masalah}

a. Bagaimana menentukan jalur terpendek untuk menentukan jalur lokasi pariwisata di Propinsi Jawa Tengah?

b. Bagaimana penerapan metode algoritma dijkstra didalam penentuan lokasi jalur pariwisata di Propinsi Jawa Tengah?

c. Bagaimana membuat aplikasi sistem informasi jalur perjalanan obyek wisata propinsi Jawa Tengah dengan metode pencarian dijkstra berbasis mobile android?

\subsection{Tujuan Penelitian}

a. Memudahkan dalam menentukan lokasi wisata di Jawa Tengah yang efisien dan efektif sehingga dapat memberikan akses yang layak dan mudah dijangkau oleh wisatawan. 
b. Menerapkan metode algoritma dijkstra didalam penentuan lokasi pariwisata di Propinsi Jawa Tengah yang efektif dan efisien.

c. Memberikan informasi kepada masyarakat berkaitan dengan lokasi pariwisata di wilayah Propinsi Jawa Tenggah dengan mudah efektif dan efisien dengan menggunakan aplikasi mobile android.

\section{PEMBAHASAN}

\subsection{Metode Penelitian}

Penelitian ini merupakan penelitian Riset dan Pengembangan (R\&D) dengan Model pengembangan Borg and Gall (1987: 775) dengan 6 langkah. Meliputi:

a. Potensi merupakan segala sesuatu yang bila didayagunakan akan memiliki nilai tambah. Masalah merupakan penyimpangan antara yang diharapkan dengan yang terjadi dalam hal ini masalah yang terjadi adalah :

1. Bagaimana menentukan jalur menuju lokasi pariwisata di Propinsi Jawa Tengah.

2. Bagaimana penerapan metode algoritma dijkstra didalam penentuan lokasi jalur pariwisata di Propinsi Jawa Tengah.

3. Bagaimana membuat aplikasi sistem informasi jalur perjalanan obyek wisata propinsi Jawa Tengah dengan metode pencarian dijkstra berbasis mobile android.

b. Pengumpulan Data

Dalam pengumpulan data disini penulis mendapatkan informasi dari buku, jurnal, literature yang berkaitan dengan wisata dan juga dinas terkait yaitu dinas pariwisata.

c. Desain Produk

Dalam langkah ini penulis melakukan mendesain produk yag diwujudkan dalam bentuk gambar atau bagan sehingga dapat digunakan sebagai pegangan untuk menilai dan membuatnya. Hasil akhir ini berupa desain produk yang baru yang dilengkap dengan spesifikasinya. Langkah desain produk dengan membuat Entity Relational Diagram, Normalisasi, database, rancangan form input dan output.

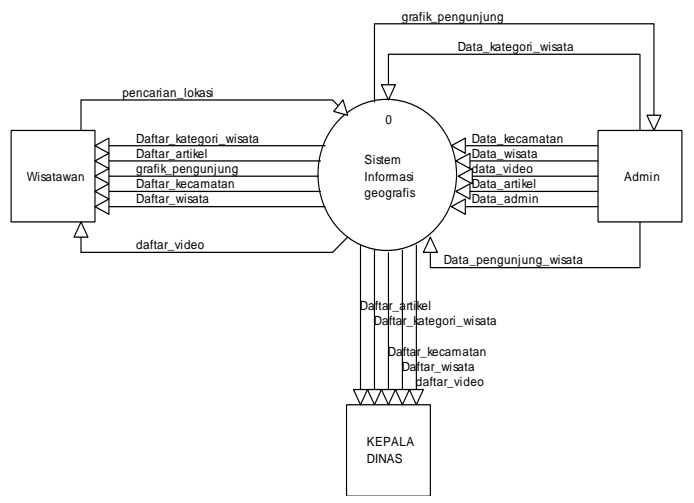

Gambar 1. Diagram Conteks
Pada Gambar 1 dijelaskan bahwa terdapat 3 entitas yaitu wisatawan sebagai pengguna sistem, kepala dinas wisata dan admin sebagai pengelola sistem. Didalam entitas wisatawan dan kepala dinas wisata terdapat aliran data yang masuk berupa daftar kategori wisata, daftar artikel, daftar kecamatan, daftar video, daftar wisata, dan pada entitas admin terdapat aliran arus data yang masuk ke sistem berupa data kategori wisata, data kecamatan, data wisata, data video, data artikel, data admin, dan login admin

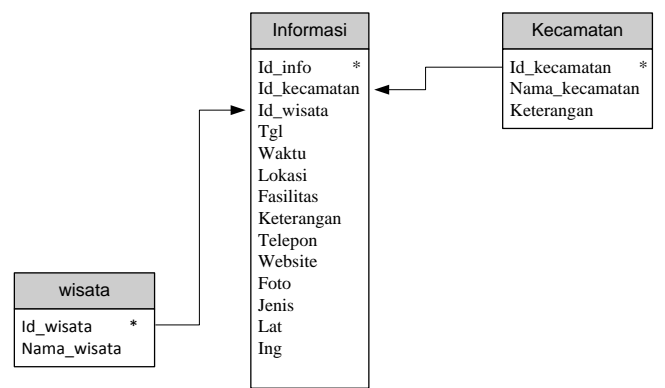

Gambar 2. Normalisasi

Dapat dijelaskan bahwa pada Gambar 2 suatu relasi dikatakan dalam bentuk normal ketiga jika berada dalam bentuk normal kedua. Setiap atribut bukan kunci tidak memiliki dependensi transitif terhadap kunci primer.

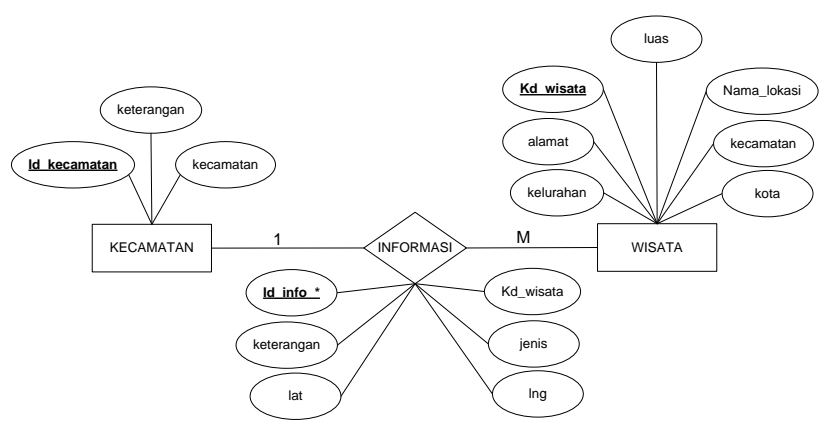

Gambar 3. Entity Relation Diagram

gambar 3 menunjukkan bahwa Terdapat relasi antara tabel kecamatan dengan wisata, dengan relasi one to many, dengan menghasilkan proses informasi. 


\begin{tabular}{|l|}
\multicolumn{1}{|c|}{ HEADER } \\
\hline Halaman Utama \\
\hline Kota \\
\hline Wisata \\
\hline Lokasi Wisata \\
\hline Jalur Wisata \\
\hline Informasi \\
\hline \\
LOGO PROPINSI JAWA TENGAH \\
\\
\end{tabular}

\section{Gambar 4. Halaman Menu Utama}

Keterangan gambar 4 :

Terdapat 4 bagian pada halaman utama aplikasinya, yaitu : bagian header, menu, isi, dan footer. Pada bagian menu terdapat menu berupa home, lokasi wisata, kota wisata, pencarian jalur, dan informasi

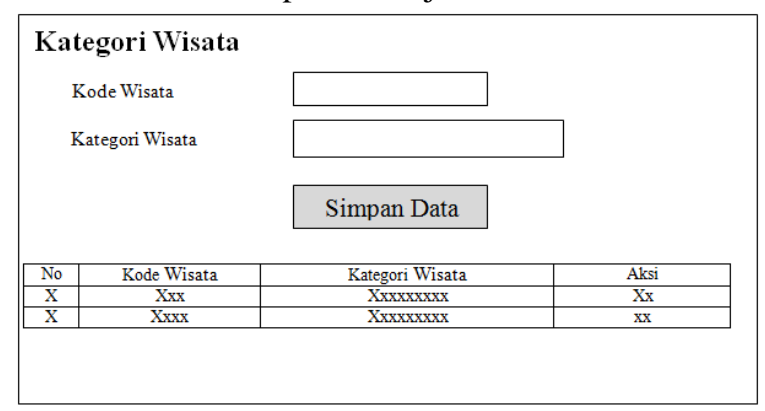

Gambar 5. Halaman Kategori Wisata

Keterangan gambar 5 :

Halaman kategori wisata digunakan untuk memasukkan data kategori wisata, berupa kode wisata dan kategori wisata.

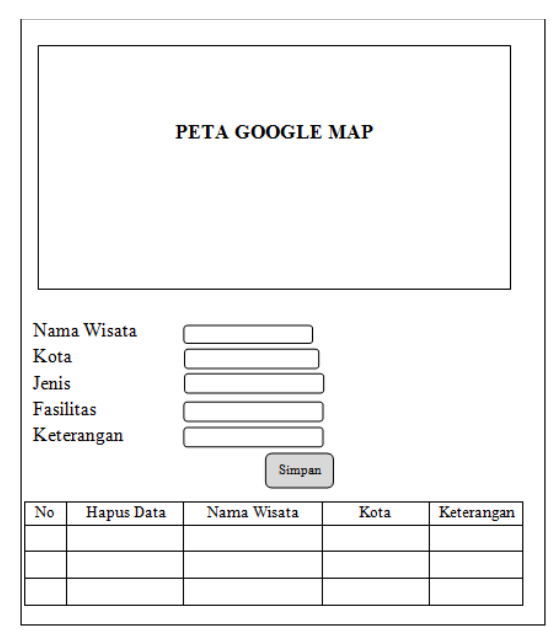

Gambar 6. Halaman Penetuan Lokasi Wisata
Keterangan gambar 6 :

Halaman penentuan lokasi wisata digunakan untuk mendata lokasi wisata yang ada di Propinsi Jawa Tengah. Data juga dihubungkan dengan google Map API.

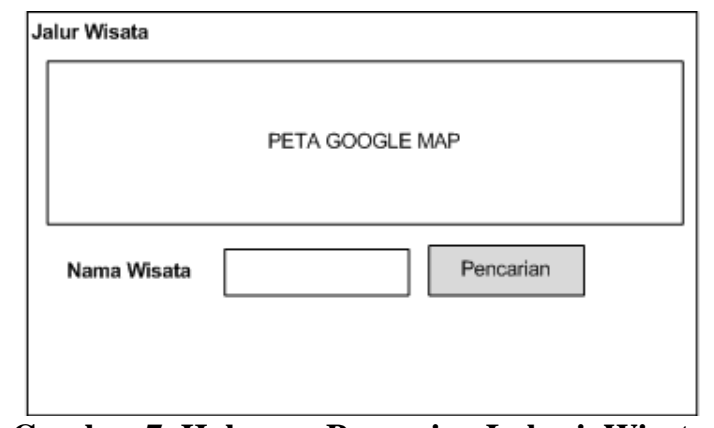

\section{Gambar 7. Halaman Pencarian Lokasi Wisata}

Keterangan gambar 7 :

Halaman pencarian jalur wisata digunakan untuk mencari data wisata disertai dengan jalur yang akan ditempuh.

d. Validasi Desain

Validasi desain merupakan proses kegiatan untuk menilai apakah rancangan produk sudah maksimal dan layak untuk digunakan

e. Revisi Desain

Dalam tahap ini seorang pakar melakukan validasi dari desain yang dihasilkan, jika tidak sesuai dengan tujuan awal maka peneliti akan melakukan perbaikan atau merevisi sesuai yang diminta oleh pakar.

f. Uji Coba Produk

Uji coba produk dilakukan setelah divalidasi dan direvisi oleh pakar. Jika dalam uji coba hasil yang dihasilkan dapat menjawab dan menyeleaikan permasalahan yang ada maka produk software akan siap digunakan.

\subsection{Hasil yang Dicapai}

Berdasarkan perancangan sistem yang telah dirancang, berikut ini merupakan implementasi dari sistem yang telah dirancang. Implementasi program dibuat dengan menggunakan bahasa pemrograman PHP menggunakan databases MySQL. 


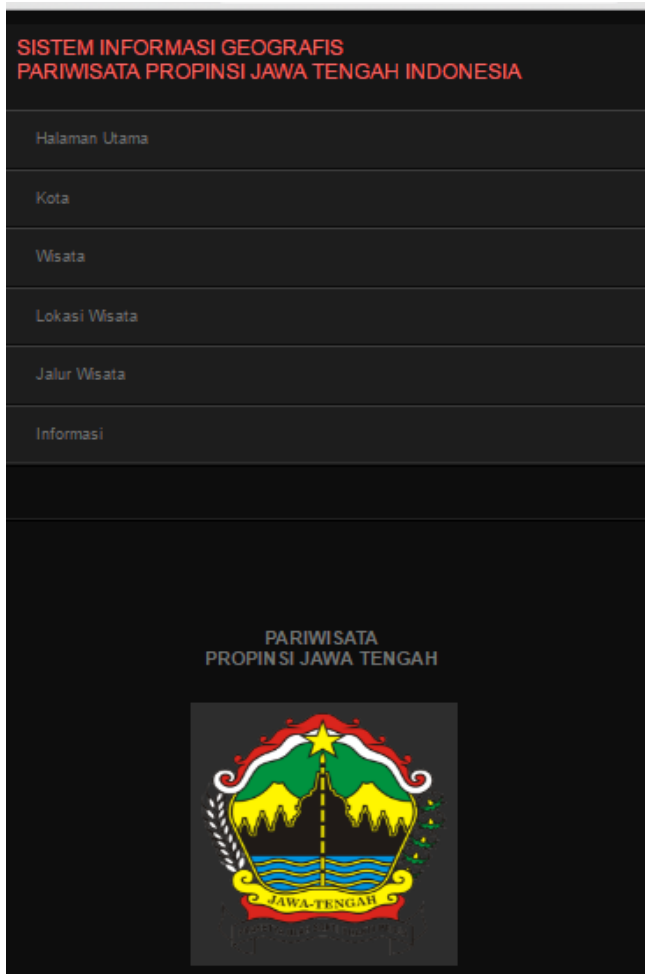

Gambar 8. Menu Utama

Keterangan gambar 8 :

Halaman menu utama terdiri dari pilihan menu. Yang terdiri dari halaman utama, kota, wisata, lokasi wisata, jalur wisata, dan informasi

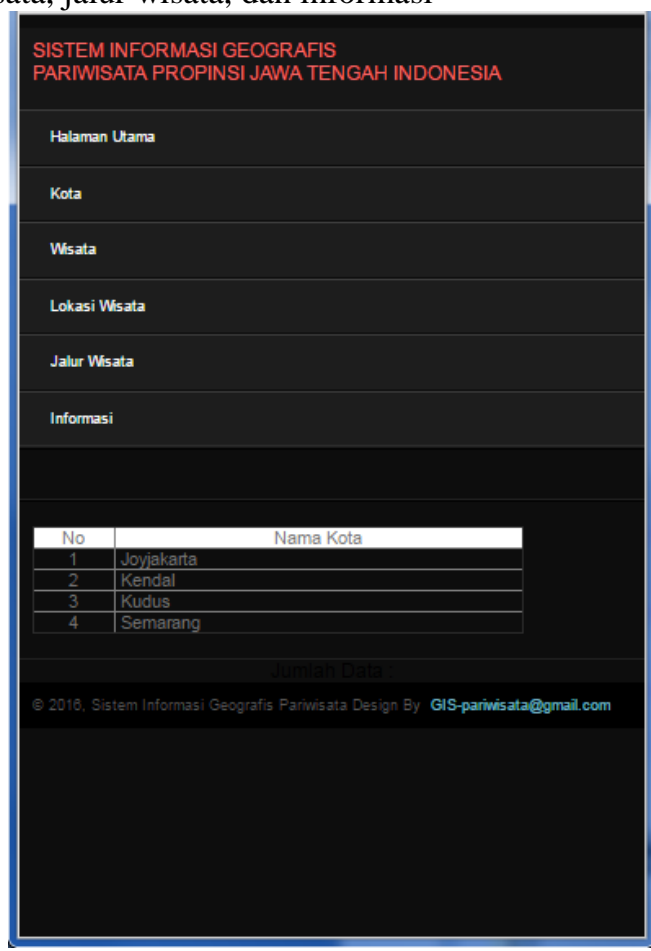

Gambar 9. Form Kota

Keterangan gambar 9 :

Halaman form kota merupakan halaman yang berisan data kota yang berada di Propinsi Jawa
Tengah. Jika nama kota dipilih maka akan muncul data wisata yang berada dikota yang sudah dipilih.

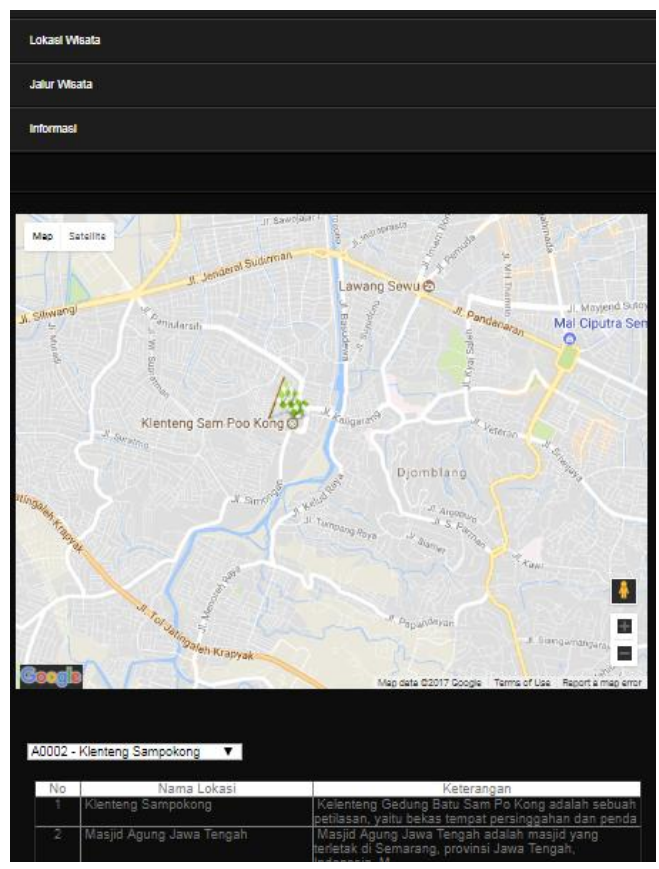

Gambar 10. Form Lokasi Wisata

Keterangan gambar 10 :

Halaman form lokasi wisata merupakan halaman yang berisan data yang berkaitan dengan lokasi wisata sesuai dengan icon wisata yang dipilih. Dari pilihan lokasi wisata ini kita diberikan informasi berkaitan dengan jalur mana yang harus kita lewati, sesuai dengan titik koordinat lokasi kita saat ini.

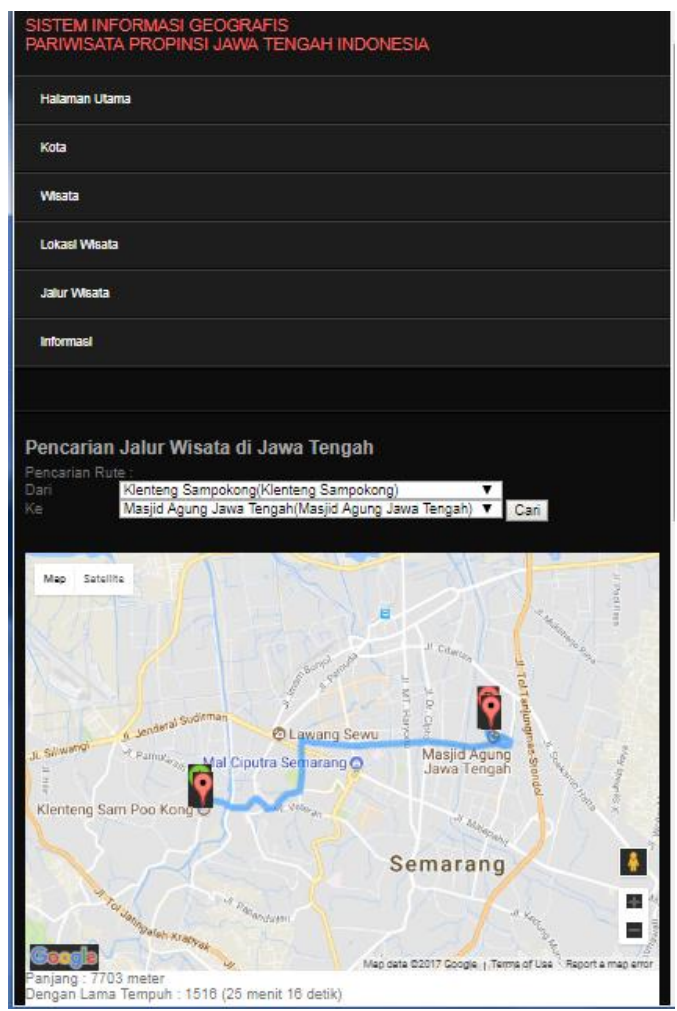

Gambar 11. Form Pencarian Jalur Wisata 


\section{Keterangan gambar 11 :}

Halaman form pencarian jalur wisata merupakan halaman yang digunakan untuk melakukan pencarian lokasi wisata pertama ke posisi lokasi wisata kedua. Dari informasi yang didapatkan adalah rute jalur terpendek dan jarak tempuh beserta waktu tempuh.

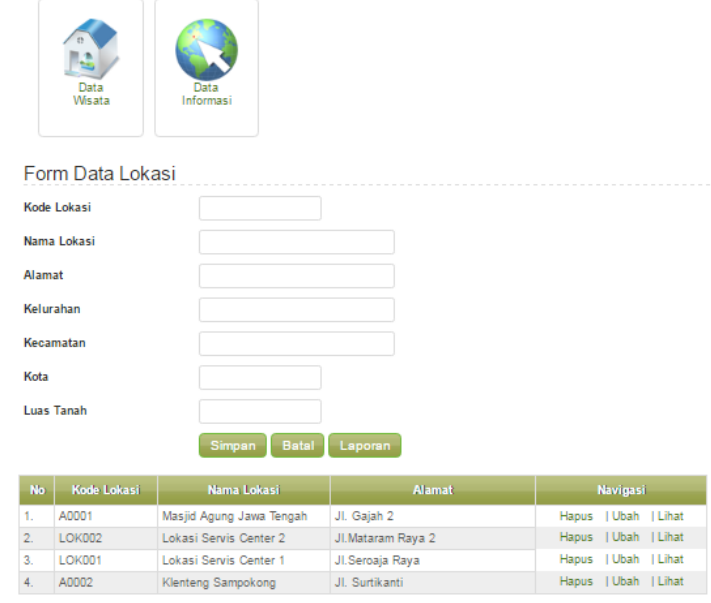

Gambar 12. Form Data Wisata

Keterangan gambar 12 :

Halaman form data wisata merupakan halaman yang digunakan untuk data wisata.

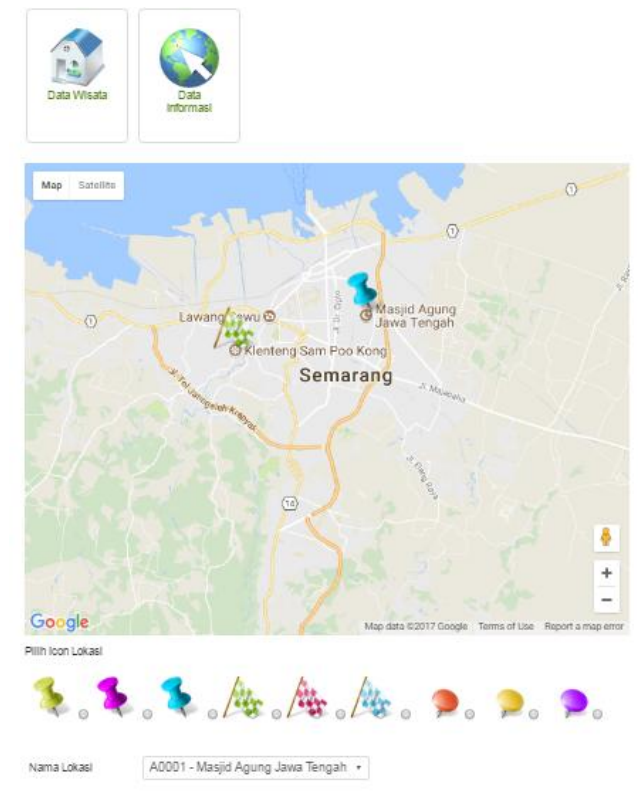

\section{Gambar 13. Form Informasi Objek Wisata}

Keterangan gambar 13 :

Halaman form info objek wisata digunakan untuk memberikan icon pada objek wisata yang langsung terhubung dengan google Map API

\subsection{Pengujian}

Melakukan pengujian alpha dan pengujian beta sebagai langkah seberapa maksimalkah penelitian yang dikerjakan. Pengujian sistem dilakukan dengan menggunakan sistem test, yaitu menguji kemampuan keseluruhan yang disediakan aplikasi dengan melihat integrasi dari semua paket sistem.

Tabel 1. Hasil Pengujian Alpha

\begin{tabular}{|c|c|c|c|}
\hline No & Kelas Uji & Teknik & $\begin{array}{c}\text { Kriteria Evaluasi } \\
\text { Kerja }\end{array}$ \\
\hline 1 & $\begin{array}{l}\text { Authentifikasi } \\
\text { Administrator }\end{array}$ & $\begin{array}{l}\text { Black } \\
\text { Box }\end{array}$ & $\begin{array}{l}\text { Simulasi sistem } \\
\text { memeriksa proses } \\
\text { login administrator, } \\
\text { berhasil atau tidak, } \\
\text { kemudian menyimpan } \\
\text { session administrator, } \\
\text { dan mematikan } \\
\text { session saat } \\
\text { administrator sudah } \\
\text { logout, sehingga } \\
\text { sistem tidak bisa } \\
\text { dibuka lagi kecuali } \\
\text { harus login kembali. }\end{array}$ \\
\hline 2 & $\begin{array}{l}\text { Pengolahan } \\
\text { data objek } \\
\text { wisata }\end{array}$ & $\begin{array}{l}\text { Black } \\
\text { Box }\end{array}$ & $\begin{array}{l}\text { Sistem dapat } \\
\text { menampilkan profil } \\
\text { kota, menambah, } \\
\text { menghapus, dan } \\
\text { mengubah data objek } \\
\text { wisata. }\end{array}$ \\
\hline 3 & $\begin{array}{l}\text { Pengolahan } \\
\text { data informasi }\end{array}$ & $\begin{array}{l}\text { Black } \\
\text { Box }\end{array}$ & $\begin{array}{l}\text { Sistem dapat } \\
\text { menampilkan } \\
\text { informasi berkaitan } \\
\text { dengan informasi data } \\
\text { objek wisata dari } \\
\text { google map API }\end{array}$ \\
\hline 4 & $\begin{array}{l}\text { Informasi } \\
\text { Kota }\end{array}$ & $\begin{array}{l}\text { Black } \\
\text { Box }\end{array}$ & $\begin{array}{l}\text { Sistem dapat } \\
\text { menampilkan data } \\
\text { kota-kota yang } \\
\text { terdapat di system } \\
\text { informasi pariwisata. }\end{array}$ \\
\hline 5 & $\begin{array}{l}\text { Pengolahan } \\
\text { data peta }\end{array}$ & $\begin{array}{l}\text { Black } \\
\text { Box }\end{array}$ & $\begin{array}{l}\text { Sistem dapat } \\
\text { menampilkan profil } \\
\text { peta menambah, } \\
\text { menghapus, dan } \\
\text { mengubah data peta. }\end{array}$ \\
\hline
\end{tabular}

Tabel 2. Pertanyaan Pengujian Betha

\begin{tabular}{|c|c|c|}
\hline Level & Pertanyaan & $\begin{array}{c}\text { Skala } \\
\text { Jawaban }\end{array}$ \\
\hline Admin & 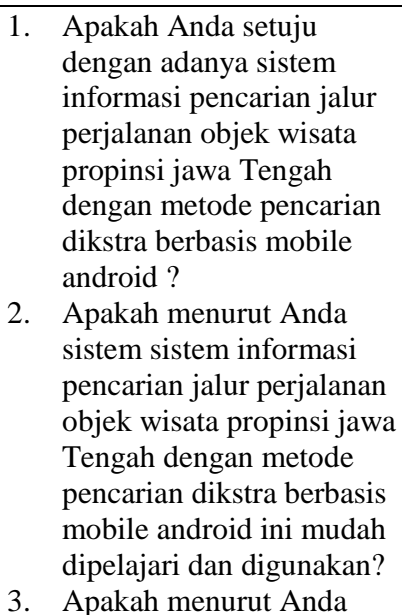 & 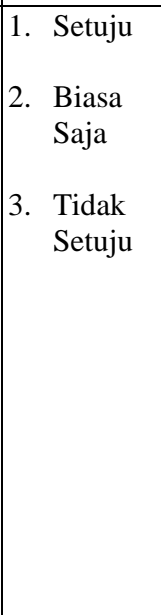 \\
\hline
\end{tabular}




\begin{tabular}{|c|c|c|c|}
\hline & 6. & $\begin{array}{l}\text { sistem informasi pencarian } \\
\text { jalur perjalanan objek } \\
\text { wisata propinsi jawa } \\
\text { Tengah dengan metode } \\
\text { pencarian dikstra berbasis } \\
\text { mobile android membantu } \\
\text { mengolah data berkaitan } \\
\text { dengan objek pariwisata } \\
\text { propinsi Jawa Tengah? } \\
\text { Apakah menurut Anda } \\
\text { sistem informasi pencarian } \\
\text { jalur perjalanan objek } \\
\text { wisata propinsi jawa } \\
\text { Tengah dengan metode } \\
\text { pencarian dikstra berbasis } \\
\text { mobile android membantu } \\
\text { pariwisata dalam } \\
\text { pencarian jalur objek } \\
\text { wisata di propinsi jawa } \\
\text { tengah? } \\
\text { Apakah menurut Anda } \\
\text { sistem ini membantu untuk } \\
\text { mengenalkan jenis wisata } \\
\text { yang ada di Indonesia? } \\
\text { Apakah antar muka sistem } \\
\text { informasi pencarian jalur } \\
\text { perjalanan objek wisata } \\
\text { propinsi jawa Tengah } \\
\text { dengan metode pencarian } \\
\text { dikstra berbasis mobile } \\
\text { android ini terlihat } \\
\text { menarik? } \\
\text { Apakah sistem informasi } \\
\text { pencarian jalur perjalanan } \\
\text { objek wisata propinsi jawa } \\
\text { Tengah dengan metode } \\
\text { pencarian dikstra berbasis } \\
\text { mobile android ini dapat } \\
\text { menampilkan yang } \\
\text { dibutuhkan ? }\end{array}$ & \\
\hline User & 1. & $\begin{array}{l}\text { Apakah anda setuju } \\
\text { dengan adanya sistem } \\
\text { informasi pencarian jalur } \\
\text { perjalanan objek wisata } \\
\text { propinsi jawa Tengah } \\
\text { dengan metode pencarian } \\
\text { dikstra berbasis mobile } \\
\text { android? } \\
\text { Apakah menurut Anda } \\
\text { sistem informasi pencarian } \\
\text { jalur perjalanan objek } \\
\text { wisata propinsi jawa } \\
\text { Tengah dengan metode } \\
\text { pencarian dikstra berbasis } \\
\text { mobile android ini mudah } \\
\text { dipelajari dan digunakan? } \\
\text { Apakah antarmuka sistem } \\
\text { informasi pencarian jalur } \\
\text { perjalanan objek wisata } \\
\text { propinsi jawa Tengah } \\
\text { dengan metode pencarian } \\
\text { dikstra berbasis mobile } \\
\text { android ini terlihat } \\
\text { menarik? } \\
\text { Apakah sistem informasi } \\
\text { pencarian jalur perialanan }\end{array}$ & 1. $\begin{array}{ll}\text { Setuju } \\
\text { 2. } & \text { Biasa } \\
& \text { Saja } \\
\text { 3. } & \text { Tidak } \\
& \text { Setuju }\end{array}$ \\
\hline
\end{tabular}

\begin{tabular}{|l|l|l|}
\hline & $\begin{array}{l}\text { objek wisata propinsi jawa } \\
\text { Tengah dengan metode } \\
\text { pencarian dikstra berbasis } \\
\text { mobile android ini dapat } \\
\text { menampilkan informasi } \\
\text { yang dibutuhkan? }\end{array}$ & \\
5. & Apakah menurut Anda \\
sistem informasi pencarian & \\
jalur perjalanan objek & \\
wisata propinsi jawa & \\
Tengah dengan metode & \\
pencarian dikstra berbasis & \\
mobile android ini & \\
membantu masyarakat & \\
untuk mengetahui objek & \\
wisata di propinsi Jawa & \\
Tengah? & \\
\hline
\end{tabular}

Berdasarkan data hasil kuesioner, dapat dicari prosentase masing-masing jawaban dengan menggunakan rumus:

$$
\mathrm{Y}=\mathrm{P} / \mathrm{Q} * 100 \%
$$

Keterangan :

$\mathrm{P}=$ Banyaknya jawaban responden tiap pertanyaan

$\mathrm{Q}=$ Jumlah responden

$\mathrm{Y}=$ Nilai Prosentase

Tabel 6.3 Hasil Pengujian Kuisioner Soal No 1

\begin{tabular}{|l|l|l|l|}
\hline Pertanyaan & Keterangan & Responden & Prosentase \\
\hline \multirow{4}{*}{1} & Setuju & 9 & $90 \%$ \\
\cline { 2 - 4 } & Biasa saja & 1 & $10 \%$ \\
\cline { 2 - 4 } & $\begin{array}{l}\text { Tidak } \\
\text { setuju }\end{array}$ & 0 & $0 \%$ \\
\hline Jumlah & 10 & $100 \%$ \\
\hline
\end{tabular}

Tabel 6.4 Hasil Pengujian Kuisioner Soal No 2

\begin{tabular}{|l|l|l|l|}
\hline Pertanyaan & Keterangan & Responden & Prosentase \\
\hline \multirow{3}{*}{2} & Setuju & 9 & $90 \%$ \\
\cline { 2 - 4 } & Biasa saja & 1 & $10 \%$ \\
\cline { 2 - 4 } & $\begin{array}{c}\text { Tidak } \\
\text { setuju }\end{array}$ & 0 & $0 \%$ \\
\hline Jumlah & 10 & $100 \%$ \\
\hline
\end{tabular}

Tabel 6.5 Hasil Pengujian Kuisioner Soal No 3

\begin{tabular}{|l|l|l|l|}
\hline Pertanyaan & Keterangan & Responden & Prosentase \\
\hline \multirow{3}{*}{3} & Setuju & 10 & $1000 \%$ \\
\cline { 2 - 4 } & Biasa saja & 0 & $0 \%$ \\
\cline { 2 - 4 } & $\begin{array}{l}\text { Tidak } \\
\text { setuju }\end{array}$ & 0 & $0 \%$ \\
\hline Jumlah & 10 & $100 \%$ \\
\hline
\end{tabular}

Tabel 6.6 Hasil Pengujian Kuisioner Soal No 4

\begin{tabular}{|l|l|l|l|}
\hline Pertanyaan & Keterangan & Responden & Prosentase \\
\hline \multirow{4}{*}{4} & Setuju & 8 & $80 \%$ \\
\cline { 2 - 4 } & Biasa saja & 2 & $20 \%$ \\
\cline { 2 - 4 } & $\begin{array}{c}\text { Tidak } \\
\text { setuju }\end{array}$ & 0 & $0 \%$ \\
\hline Jumlah & 10 & $100 \%$ \\
\hline
\end{tabular}


Tabel 6.7 Hasil Pengujian Kuisioner Soal No 5

\begin{tabular}{|l|l|l|l|}
\hline Pertanyaan & Keterangan & Responden & Prosentase \\
\hline \multirow{4}{*}{5} & Setuju & 10 & $100 \%$ \\
\cline { 2 - 4 } & Biasa saja & 0 & $0 \%$ \\
\cline { 2 - 4 } & $\begin{array}{c}\text { Tidak } \\
\text { setuju }\end{array}$ & 0 & $0 \%$ \\
\hline Jumlah & 10 & $100 \%$ \\
\hline
\end{tabular}

Tabel 6.8 Hasil Pengujian Kuisioner Soal No 6

\begin{tabular}{|l|l|l|l|}
\hline Pertanyaan & Keterangan & Responden & Prosentase \\
\hline \multirow{4}{*}{6} & Setuju & 9 & $90 \%$ \\
\cline { 2 - 4 } & Biasa saja & 1 & $10 \%$ \\
\cline { 2 - 4 } & $\begin{array}{c}\text { Tidak } \\
\text { setuju }\end{array}$ & 0 & $0 \%$ \\
\hline Jumlah & 10 & $100 \%$ \\
\hline
\end{tabular}

Tabel 6.9 Hasil Pengujian Kuisioner Soal No 7

\begin{tabular}{|l|l|l|l|}
\hline Pertanyaan & Keterangan & Responden & Prosentase \\
\hline \multirow{4}{*}{7} & Setuju & 8 & $80 \%$ \\
\cline { 2 - 4 } & Biasa saja & 2 & $20 \%$ \\
\cline { 2 - 4 } & $\begin{array}{c}\text { Tidak } \\
\text { setuju }\end{array}$ & 0 & $0 \%$ \\
\hline Jumlah & & 10 & $100 \%$ \\
\hline
\end{tabular}

Tabel 6.13 Hasil Pengujian Kuisioner User Soal No 1

\begin{tabular}{|l|l|l|l|}
\hline Pertanyaan & Keterangan & Responden & Prosentase \\
\hline \multirow{4}{*}{1} & Setuju & 9 & $90 \%$ \\
\cline { 2 - 4 } & Biasa saja & 1 & $10 \%$ \\
\cline { 2 - 4 } & $\begin{array}{c}\text { Tidak } \\
\text { setuju }\end{array}$ & 0 & $0 \%$ \\
\hline Jumlah & 10 & $100 \%$ \\
\hline
\end{tabular}

Tabel 6.14 Hasil Pengujian Kuisioner User Soal No 2

\begin{tabular}{|l|l|l|l|}
\hline Pertanyaan & Keterangan & Responden & Prosentase \\
\hline \multirow{4}{*}{2} & Setuju & 9 & $90 \%$ \\
\cline { 2 - 4 } & Biasa saja & 1 & $10 \%$ \\
\cline { 2 - 4 } & $\begin{array}{c}\text { Tidak } \\
\text { setuju }\end{array}$ & 0 & $0 \%$ \\
\hline Jumlah & 10 & $100 \%$ \\
\hline
\end{tabular}

Tabel 6.15 Hasil Pengujian Kuisioner User Soal No 3

\begin{tabular}{|l|l|l|l|}
\hline Pertanyaan & Keterangan & Responden & Prosentase \\
\hline \multirow{4}{*}{3} & Setuju & 10 & $1000 \%$ \\
\cline { 2 - 4 } & Biasa saja & 0 & $0 \%$ \\
\cline { 2 - 4 } & $\begin{array}{l}\text { Tidak } \\
\text { setuju }\end{array}$ & 0 & $0 \%$ \\
\hline \multicolumn{2}{|l}{ Jumlah } & 10 & $100 \%$ \\
\hline
\end{tabular}

Tabel 6.16 Hasil Pengujian Kuisioner User Soal No 4

\begin{tabular}{|l|l|l|l|}
\hline Pertanyaan & Keterangan & Responden & Prosentase \\
\hline \multirow{4}{*}{4} & Setuju & 10 & $1000 \%$ \\
\cline { 2 - 4 } & Biasa saja & 0 & $0 \%$ \\
\cline { 2 - 4 } & $\begin{array}{l}\text { Tidak } \\
\text { setuju }\end{array}$ & 0 & $0 \%$ \\
\hline \multicolumn{2}{|l|}{ Jumlah } & 10 & 10 \\
\hline
\end{tabular}

Tabel 6.17 Hasil Pengujian Kuisioner User Soal No 5

\begin{tabular}{|c|l|l|c|}
\hline Pertanyaan & Keterangan & Responden & Prosentase \\
\hline \multirow{4}{*}{5} & Setuju & 10 & $1000 \%$ \\
\cline { 2 - 4 } & Biasa saja & 0 & $0 \%$ \\
\cline { 2 - 4 } & $\begin{array}{c}\text { Tidak } \\
\text { setuju }\end{array}$ & 0 & $0 \%$ \\
\hline \multicolumn{2}{|c|}{ Jumlah } & 10 & 10 \\
\hline
\end{tabular}

\section{KESIMPULAN}

Berisi berbagai kesimpulan yang diambil berdasarkan penelitian yang telah dilakukan.Berisi pernyataan singkat tentang hasil yang disarikan dari pembahasan. Saran dapat dituliskan pada bagian paling akhir.

Berdasarkan hasil penelitian, analisis, perancangan dan pembuatan program sampai dengan tahap penyelesaian, maka dapat ditarik beberapa simpulan sebagai berikut :

Sistem Informasi Geografis Pencarian Jalur Perjalanan Objek Wisata Propinsi Jawa Tengah dengan Metode Pencarian Djikstra Berbasis Mobile Android dapat memberikan informasi yang cukup memadahi berupa informasi objek wisata di Jawa Tengah dapat diterapkan dengan menggunakan Google Maps, dimana data dan sistemnya terorganisasi dan terintegrasi dengan baik.

Berdasarkan kekurangan dan keterbatasan yang ada pada Sistem informasi pencarian jalur perjalanan objek wisata propinsi jawa Tengah dengan metode pencarian dikstra berbasis mobile android, maka disarankan :

a. Sistem dapat memberikan informasi lebih detail tentang wisata seluruh propinsi Jawa Tengah.

b. Menambahkan fasilitas translate pada bahasa lain.

\section{PUSTAKA}

Erwin, H. 2010, ArcView GIS Pengukuran dan Pemetaan Areal Kerja Skala Besar, Yogyakarta, Graha Ilmu.

Budi, P.S. \& Kurnialensya, 2014. Prosiding SEMNASTEKMEDIA, Vol 2, No.1: Sistem Informasi Pembelajaran "ASIK" berbasis Tryout Untuk Ujian Nasional SMP di Wilayah Semarang,(online)

(https://ojs.amikom.ac.id/index.php/semnastek nomedia/article, diakses 2 Januari 2019)

Kurnialensya, T., 2017. Jurnal IJSN (online), Vol 6, No.3 : Pemetaan Wilayah Dalam Penentuan Lokasi Usaha Waralaba Berbasis Google Maps API (Application Programming Interface),

(http://ijns.org/journal/index.php/ijns/article/vie w/1470, diakses 2 Januari 2019)

Kurnialensya, T. \& Prihatmoko, S., 2014. Prosiding SNIK Unnes: Sistem Informasi Geografis Populasi Flora dan Fauna Indonesia Berbasis Google Maps API (Application Programming Interface,(online), 
(https://ilkom.unnes.ac.id/snik/2014/prosiding/, diakses 2 Januari 2019)

Kharistiani, E. \& Ariwibowo, E., 2013. Jurnal JSTIF: Sistem Informasi Geografis Pemetaan Potensi SMA/SMK Berbasis Web (Studi Kasus : Kabupaten Kebumen), (online), (https://media.neliti.com/media/publications/21 1222-sistem-informasi-geografis-pemetaanpote.pdf, diakses 2 Januari 2019)

Sylvia, T. \& Sudarsono, B., 2016. Jurnal Geodesi Undip Volume 5 No.2 : Aplikasi Sistem Informasi Geografis (SIG) Untuk Pemetaan Pasar Tradisonal di Kota Semarang Berbasis web,(online),

https://ejournal3.undip.ac.id/index.php/geodesi/ article/view/11606, diakses 2 Januari 2019) 